UNITED STATES

DEPARTMENT OF THE INTERIOR

GEOLOGICAL SURVEY

EXTENT AND FREQUENCY OF FLOODS

ON CROSSWICKS CREEK FROM

NEW EGYPT TO BORDENTOWN, N.J.

By

Herbert J. Freiberger

and

Thomas G. Ross

Prepared in cooperation with

New Jersey Department of Environmental Protection

Division of Water Resources

Trenton, New Jersey

March 1971

Open-file report 

PREFACE

This report contains information on the extent, depth and frequency of flooding on Crosswicks Creek. It is intended to provide the basic data essential for proper development and maximum use of flood plains in a manner consistent with the flood hazard involved.

This flood inundation study is part of an investigative program financed through a cooperative agreement between the U.S. Geological Survey and the New Jersey Department of Environmental Protection, Division of Water Resources. This report was prepared under the general supervision of J. E. McCall, district chief, U.S. Geological Survey, Trenton, N.J. Technical guidance was given by J. F. Bailey, hydrologist, U.S. Geological Survey, Arlington, Virginia, and A. C. Lendo, hydrologist, U.S. Geological Survey, Trenton, N.J. 

CONTENTS

Page

Preface................................ II

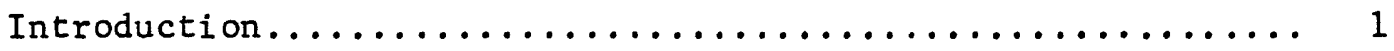

Purpose and scope......................... 1

Location and description of the area............. 2

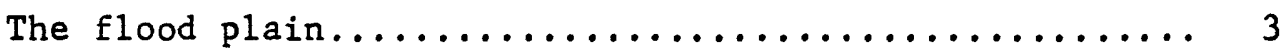

Method of analysis........................... 4

Data available........................... 5

Determination of floodway and flood hazard area floods.. 7

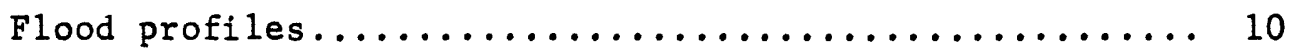

Use of frequency and flood profiles................ 12

Areal extent of flooding..................... 12

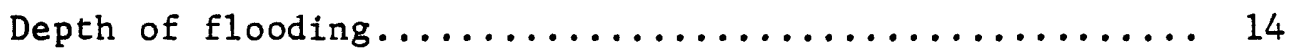

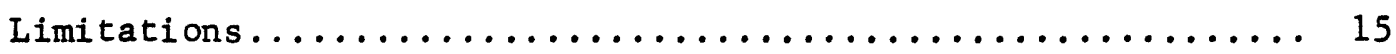

Selected bibliography........................ 17 
VI

ILIUSTRATIONS

Plate 1.--Floods on Crosswicks Creek from New Egypt to Bordentown, N.J.................. In pocket

Page

Figure 1.--Regionalized and Log Pearson Type III frequency

curves for Crosswicks Creek at Extonville...... 19

2.--Regionalized frequency curve for Crosswicks Creek

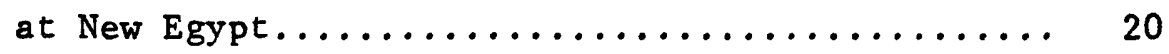

3.--Tidal and(or) fluvial frequency curve for Delaware

River at the mouth of Crosswicks Creek......... 21

4.--Profiles of Crosswicks Creek................. 23

5-8.--Cross sections of Crosswicks Creek............ 25

TABLES

Table 1.--Flood-crest data for Crosswicks Creek............ 29

2.--Flood data for bridges across Crosswicks Creek...... 31

3.--Mean sea level reference points............. 33 


\title{
EXTENT AND FREQUENCY OF FLOODS \\ ON CROSSWICKS CREEK FROM \\ NEW EGYPT TO BORDENTOWN, N.J.
}

\author{
By \\ Herbert J. Freiberger \\ and \\ Thomas G. Ross \\ INTRODUCTION

\section{Purpose and Scope}

The land adjoining a watercourse is subject to flooding from overbank flow. Development of the flood-plain areas has often taken place without consideration of the flood threat, either because it was unknown or there was insufficient information for reasonable estimates of the risk involved in such development.

This report presents information on the extent, depth, and frequency of floods on Crosswicks Creek. The analysis presents specific information on the floodway and flood hazard area floods as adopted by New Jersey and described in "Flood Hazard Report No. 1, Delineation of Flood Hazard Areas" by Anderson-Nichols \& Co. Inc., Consultant (1967). The information was based on records since 1940 for the stream-gaging station at Extonville, peak discharge records collected since 1967 at New Egypt, cross-sectional data which was utilized for computation of flood profiles by step-backwater analysis as described by Bailey and Ray (1966), and other technical data 
bearing upon the recurrence and size of floods, including tidal flooding in the lower reach of the study area.

This information is intended as an aid to the state and local governmental agencies for planning and regulating the use of the areas subject to inundation. Recommendations for land use, or limitations thereof, are not made in this report. Suggestions and criteria for land use may be found in Dola (1961); White (1961); American Society of Civil Engineers Task Force on Flood Plain Regulations (1962); Goddard (1963); and Bue (1967).

\section{Location and Description of the Area}

The area covered by this report (see plate 1) consists of the lowlands along Crosswicks Creek from its mouth to the head of Oakford Lake just above New Egypt, a distance of 124,600 ft (23.6 miles). Communities located on and near the stream are New Egypt, Crosswicks, Groveville, Bordentown, Yardville and White Horse.

Crosswicks Creek lies entirely in the Coastal Plain which is composed of a series of gently seaward dipping beds of clay, silt, sand, and gravel. Below the Coastal Plain sediments, dense, relatively impermeable metamorphic rocks form the basement complex. The thickness of the sediments in the study area ranges from about 200 feet at Bordentown to about 1,100 feet at New Egypt. 
The Crosswicks Creek basin is a region of low relief, with an occasional rise such as Taylor Mountain, southwest of New Egypt.

The drainage area above New Egypt is relatively flat and a large percentage of the upper basin consists of lakes and swamps. From New Egypt to head of tide (between Crosswicks and Groveville), Crosswicks Creek flows north and west in a valley 40 to $60 \mathrm{ft}$ deep, and with an average slope of about $3 \mathrm{ft}$ per mile. The slope is relatively flat in the tide-affected reach from Groveville to the Delaware River, with large overflow plains.

\section{The Flood Plain}

Upstream of U.S. Highway 130, the normal channel of Crosswicks Creek is bordered by a flood plain of low, relatively flat land which is inundated at least once a year on the average. The width of this flood plain varies between 200 and $1,500 \mathrm{ft}$, with the narrower areas generally lying in the upper reaches between New Egypt and Extonville. Below U.S. Highway 130, the reach is affected by tidal and(or) fluvial flooding from the Delaware River, and the flood plain is extremely wide; up to a half mile in some places.

Most of the flood plain is used for farming, pasture land or is undeveloped, with the exception of the areas around the communities mentioned previously. The only significant industry now located on the flood plain is the Anchor Thread Company on Crosswicks Creek in Groveville. Hamilton Township Sewage Treatment Plant is located on Crosswicks Creek downstream of U.S. Highway 206. In addition, the Bordentown Pumping Station is on Crosswicks Creek in White Horse. 


\section{METHOD OF ANALYSIS}

Mean annual, floodway, and flood hazard area floods were determined as described in the "New Jersey Flood Hazard Report No. 1, Delineation of Flood Hazard Areas" by Anderson-Nichols \& Co., Inc., Consultant (1967) which refers to use of Water Resources Circular 13 by D. M. Thomas (1964). The method outlined in these two reports is a regionalized approach to the determination of the flood discharges at ungaged sites. However, since continuous records of streamflow have been collected since 1940 on Crosswicks Creek at Extonville and peak discharges since 1967 were determined at New Egypt, these data were utilized for a better determination of the floods as explained later under "Determination of Floodway and Flood Hazard Area Floods." Profiles of the floods along the selected reach were computed by the step-backwater method, described by Bailey and Ray (1966). Field data collected for the computations on an electronic computer were cross sections of the channel at intervals along the reach to a common datum, and values of the roughness coefficient. Rating curves which defined the stagedischarge relations at Extonville and New Egypt were used as checks of the computed elevations for the selected floods.

Profiles were computed with initial conditions in the lower or tide affected reach as follows:

1. A mean annual flood on Crosswicks Creek superimposed on a 100-year recurrence interval stage of 16.5 feet above mean sea level of the Delaware River at the mouth of Crosswicks Creek. 
2. The floodway flood on Crosswicks Creek superimposed on a mean spring high tide stage of 8.5 feet above mean sea level of the Delaware River at the mouth of Crosswicks Creek.

3. The flood hazard flood on Crosswicks Creek superimposed on a mean spring high tide stage of 8.5 feet above mean sea level of the Delaware River at the mouth of Crosswicks Creek.

The final step was the preparation of the flood-inundation map showing the areas inundated by the floodway and flood hazard area floods. This map was prepared on the basis of the profile for the particular flood, plotting the extent of inundation at each cross section, and delineating between cross sections by interpolation between contours. The profile used for the flood hazard area inundation was whichever was higher as determined by steps 1 and 3 above.

\section{Data Available}

Continuous record is available for the station, Crosswicks Creek at Extonville, from August 1940 to October 1951 and October 1952 to the current time. In addition, a crest-stage gage to record flood peaks was installed on Crosswicks Creek at New Egypt in November 1967 (see plate 1 for locations of these stations).

A flood frequency curve computed by the log-Pearson Type III method (Water Resources Council, 1967) was available for the Extonville site. This method was adopted as the base or standard method for computing flood frequencies by the Water Resources 
Council and member Federal agencies in 1967. Correlation of peak discharges at New Egypt with corresponding peak discharges at the Extonville gage was available for analysis.

The stage-frequency curve shown in figure 3 represents a combination of tidal and(or) fluvial flooding at the mouth of Crosswicks Creek. This curve was developed from a curve presented by the U.S. Corps of Engineers (House Document No. 348, 1964), and other flood data. It is essentially tidal at the lower end and fluvial at the upper end.

Since the basin is sparsely populated, little information was available as to flood-crest elevations for past floods. The few historical flood elevations that were obtained are shown in table 1. The highest flood known on Crosswicks Creek upstream from head of tide is that of September 1938, and the highest flooding in the tidal reach is that of August 1955.

Cross sections were run at intervals of 800 to 1,000 feet along Crosswicks Creek from U.S. Highway 206 at Bordentown to the head of Oakford Lake above New Egypt. In addition, roughness values for Manning's " $n$ " for each cross section and sub-reach were selected. The above data constituted the required input for the step-backwater computer program. The collection of bridge and dam data was included in the field survey (table 2). 
A base map (plate 1) prepared from the U.S. Geological Survey 7 1/2 minute topographic maps (Trenton East, 1957; Allentown, 1957; New Egypt, 1957) at a scale of 1:24,000 with a contour interval of 10 feet was used to define the areal extent of flooding. Twelve of the available cross sections were used to further illustrate the areal extent of flooding (figs. 5-8).

Stream stationing used in this report is the distance, in feet, measured above the mouth along the centerline of the stream. Measurements for stationing were obtained from U.S. Geological Survey maps and from transit-stadia field plots.

Vertical control was established using bench mark data furnished by the New Jersey Geodetic Control Survey, Mercer County, and Burlington County. Bench marks and other reference marks used for vertical control are listed in table 3 . Elevations used in this report are given in feet above mean sea level.

\section{Determination of Floodway and Flood Hazard Area Floods}

New Jersey floodway and flood hazard area design floods are used by the State of New Jersey for planning purposes and control of encroachments on the stream channel.

As defined in the report by Anderson-Nichols Co., Inc., Consultant (1967) the New Jersey Floodway Design and New Jersey Flood Hazard Area Design Floods are as follows:

Floodway - The channel and portions of the adjacent floodplain necessary to preserve the natural regimen of a stream for the reasonable passage of the floodway design flood. 
Flood Hazard Area - The floodway and any additional portions of the floodplain inundated by the flood hazard area design flood. The magnitude of the floodway and flood hazard area floods were determined by procedures described in the New Jersey Flood Hazard Report No. 1 with reference to curves and relations as given in the New Jersey Water Resources Circular No. 13, First, the mean annual flood is determined for the particular site on the stream from the drainage area vs mean annual flood curve (for sites with 2 percent of area as lakes and swamps) for the region in which the stream flows. The mean annual flood is then adjusted by a factor determined from a curve of adjustment factor vs lake and s wamps area, in percent of drainage area. The floodway and flood hazard area floods are then determined by applying appropriate multiples to the adjusted mean annual flood. The frequency curve for the site is then prepared by the method described in New Jersey Water Resources Circular No. 13.

Crosswicks Creek basin is close to a poorly defined boundary between different flood-frequencies and hydrologic areas, as outlined in Water Resources Circular 13. Therefore, frequency curves were prepared for Crosswicks Creek at Extonville (drainage area $83.6 \mathrm{sq} \mathrm{mi}$ ) both by using Area 3 and Region $\mathrm{C}$ curves, as recommended by the reference report, and by using Area 2 and Region $B$ curves. These two frequency curves were than compared to the frequency curve based on the measured annual flood discharges at the Extonville station and computed by the log-Pearson Type III method (fig. 1). This comparison indicated that the mean 
annual flood and the applicable multiples to determine the floodway and flood hazard area floods were better based on the Area 2 and Region $B$ curves for most of the study area (from head of tide to the mouth of Lahaway Creek, a major tributary at station 100,000 ).

However, the use of the Area 2 and Region B curves for the flood computations at the New Egypt site gives results that are low based on the actual peak discharge data collected at the crest-stage gage. The mean annual flood adjustment factor for the large percentage of area of lakes and swamps above New Egypt, as determined from the given relationship, may need further study to give better results or it may be that the river reach upstream from the mouth of Lahaway Creek may be in a different hydrologic area. Due to these uncertainties, a separate analysis was made for this relatively short reach with a 25 percent increase in drainage area from the upstream to downstream ends of the reach. The mean annual flood discharge for Crosswicks Creek at New Egypt was determined from the relation of the peak discharges recorded at New Egypt to the corresponding peak discharges at the Extonville station. Mean annual flood discharges for other sites in the reach from mouth of Lahaway Creek to head of Oakford Lake were determined by multiplying the New Egypt mean annual flood by the drainage area ratio. The floodway and flood hazard area floods were then determined by applying the same multiples as for sites downstream from Lahaway Creek. Thus the actual flood data collected at Extonville and New Egypt were given major weight in the analysis. 
The mean annual, floodway, and flood hazard area flood discharges thus computed are given for bridge and dam sites on Crosswicks Creek in table 1 .

From the Area 2, Region B frequency curve for the Extonville station (fig. 1) the recurrence interval for the floodway flood is about 60 years and the flood hazard area flood is approximately 180 years. The recurrence intervals for these two floods are approximately the same at other sites along the river including the New Egypt site as given in figure 2.

\section{Flood Profiles}

Profiles for the flood hazard flood, floodway flood, and mean annual flood are shown in figure 4. These profiles were defined by computations utilizing cross sectional data in the step-backwater computer program. The thalweg data was obtained from field surveys at each cross section in the study.

The highest water surface profile between stations 0 to 33,000 feet represents the flood elevation which would result from the simultaneous occurrence of a 100-year frequency backwater effect from the Delaware River $(16.5 \mathrm{ft})$ and a Crosswicks Creek mean annual flood discharge of 2,800 cubic feet per second. The flood plain in this six mile reach is very wide (especially below U.S. Route 130) and it can be seen from the profile that the mean annual flood is quickly dissipated in the high conveyance capacity of the channel downstream from the head of tide. The mean annual flood is affected 
by backwater from tides up to the New Jersey Turnpike at station 44,000. If the flood hazard flood had been superimposed on the same high tide, the water surface elevation up to the Turnpike would have been slightly higher. This condition, however, was not delineated as the probability of these two extreme events occurring at the same time is very remote.

The slope of the water surface profiles of the mean annual, floodway, and flood hazard floods conform very nearly to average slope of the streambed in the reach which is not tide affected. An exception to this is the abrupt changes which are shown at most bridges, indicating the difference in upstream and downstream water surface elevations. The drops through the bridges represent backwater at the upstream side caused when the hydraulic characteristics of the bridge openings control the upstream water surface elevation. The water surface below the bridge is controlled by the hydraulics of the downstream channel. The actual amount of fall at bridges was computed by indirect methods utilizing bridge geometry collected in field surveys and applicable discharges.

The degree of control exercised by the bridge under normal conditions is dependent on discharge and channel conditions downstream of the bridge. Accumulations of debris or channel enlargement or fill could significantly alter the drop in water surface through the bridge, and may also affect the areal extent of flooding upstream of the bridge. 
USE OF FREQUENCY AND FLOOD PROFILES

The primary use of the flood data in this report is to determine the areal extent and depth of flooding that would occur during the floodway design and flood hazard design floods.

Important secondary uses are (1) to determine the areal extent of a flood of a specific frequency, and (2) to estimate the depth of flooding at a specific location for a given frequency.

When dealing with the frequency and profile relations applied to practical problems at a specific location, elevation of that point in feet above mean sea level will be required. These elevations should be obtained by differential leveling and should be referenced to mean sea level, datum of 1929 , which is equivalent to the New Jersey Geodetic Control Survey datum. The list of bench marks and reference marks in table 3 may prove to be helpful as a starting point for leveling work.

\section{Areal Extent of Flooding}

The areas inundated by the floodway and flood hazard floods are shown on plate 1 . The flood boundaries delineated along tributary streams represent the areas inundated by backwater from the floodway and flood hazard floods on Crosswicks Creek. More extensive flooding on these tributary streams could occur as a result of heavy local thunderstorms on the tributary basin and would have a different frequency and profile. 
The areal extent of flooding of a specified frequency at any location along Crosswicks Creek can be found by determining the elevation for the flood of the particular frequency. This point may then be located by levels in the field or on the base map (plate 1) by interpolation between contours and(or) the elevations for the flood hazard and floodway floods at the particular location. In the lower reach, affected by tidal and(or) fluvial backwater from the Delaware River, the elevation of the water surface for a specified frequency can be determined by reference to figure 3 .

At the gaging station at Extonville, the elevation for a flood of a specified frequency may be determined by reference to the Area 2, Region B curve given in figure 1. For any other location, between Groveville Road and mouth of Lahaway Creek, the elevation for a 30-year recurrence interval flood, as an example, may be determined by the following procedure.

1. Locate the point of interest on the base map (plate 1) and determine the stream stationing which, for illustration, is station 80,000 .

2. Refer to the water surface profiles (fig. 4). Note that the elevation for the 30-year flood will fall between the profiles for the mean annual flood (2.33-year frequency) and the floodway flood (60-year frequency, same as determined for site of Extonville station). 
14

3. Refer to the Area 2, Region B curve given in figure 1. For the Extonville site, we determine the elevations for the mean annual, 30-year frequency, and floodway floods as $34.5,37.2$, and $37.8 \mathrm{ft}$, respectively. We note the difference of $3.3 \mathrm{ft}$ between the mean annual and floodway floods, and that the 30-year flood is 0.6 lower than the floodway flood.

4. Refer to figure 4. At station 80,000 , we find that the difference between the elevations of $39.2 \mathrm{ft}$ for the mean annual flood and $42.4 \mathrm{ft}$ for the floodway flood is $3.2 \mathrm{ft}$, and thus the elevation of the 30-year flood is $42.4-0.6$ or $41.8 \mathrm{ft}$. Proportional ratios would be used if this difference was substantially greater or less than at the Extonville station. In this case, however, it is close enough to say that the desired elevation is $0.6 \mathrm{ft}$ lower than the floodway flood.

The procedure would be the same for the reach upstream from the mouth of Lahaway except that the frequency curve for Crosswicks Creek at New Egypt (fig. 2) would be used.

\section{Depth of Flooding}

Twelve cross sections, figures 5-8, are shown in this report to illustrate the depth of flooding at selected sites on Crosswicks Creek. Flood hazard, floodway, and mean annual flood elevations determined from figure 4 are shown on these cross sections. For other sites along the stream, the depth of flooding can be determined by subtracting the ground elevation from the flood elevation. Ground 
elevation can be determined from the topographic map (plate 1) or, preferably, from ground surveys. Flood elevations can be found from figure 4 for any location for which the distance above the mouth has been scaled from the map (plate 1).

\section{LIMITATIONS}

The flood data presented in this report can be used in land use planning, flood insurance studies, and efficient regulation of development in the Crosswicks Creek flood plain. However, the procedures recommended herein must be used with full knowledge of the limitations involved.

The term "recurrence interval" used in flood mapping studies is not meant to imply any regularity of occurrence. Floods occur on a very irregular basis with no advance warning. The term "recurrence interval" as used in flood-frequency studies is defined as the average interval of time within which a flood of a given magnitude will be equaled or exceeded once. For example, a flood having a recurrence interval of 25 -years indicates that a flood of that magnitude will be equaled or exceeded, on the average, four times in 100 years.

Among the limitations is the accuracy of the higher recurrence intervals shown on figures 1 and 2 . These frequency curves were based on regional relations defined by Thomas (1964) and on the basis of 28 years of record at Extonville and 3 years of record at 


\section{6}

New Egypt. The hydrologic conditions of an area do not always remain constant. Changes in hydrologic characteristics of the stream may very well alter the flood-frequency relation. Increased urbanization will result in greater storm runoff and higher peak discharges. Channel improvements such as dredging or straightening as well as filling or building on the flood plain will have an altering effect on the flood profile. The construction of bridges and dams across the stream must also be considered as having potential for changing the flood profile.

Therefore, for structures built upon the flood plain, it would be prudent to provide a foot or two of extra elevation above that shown to be needed in this study. Extra allowance would especially be advisable for structures that are highly susceptible to flood damage and are difficult to flood proof or evacuate after warning. 
SELECTED BIBLIOGRAPHY

American Society Civil Engineers, Task Force on Flood Plain Regulations, Flood Control Committee of the Hydraulics Division, 1962, Guide for the development of flood plain regulations, progress report: Am. Soc. Civil Engineers, Proc., v. 88, no. HY 5, p. 73-119. Anderson-Nichols \& Co., Inc., Consultant, 1967, Delineation of flood hazard areas: New Jersey Dept. Conserv. and Econ. Devel., Div. Water Policy and Supply, 54 p.

Bailey, J. F., Ray, H. A., 1966, Definition of stage-discharge relation in natural channels by step-backwater analysis: U.S. Geo. Survey Water-Supply Paper 1869-A, 22 p.

Bue, C. D., 1967, Flood Information for Flood-Plain Planning, Geological Survey Circular 539.

Dola, S., 1961, Flood damage alleviation in New Jersey: New Jersey Dept. Conserv. and Econ. Devel., Div. Water Policy and Supply, Water Resources Circ. 3, 20 p.

Goddard, J. E., 1963, Flood plain management improves man's environment: Am. Soc. Civil Engineers, Proc., v. 89, no. WW4 , - p. 67-84.

Gumbel, E. J., 1945, Flood estimated by probability method: Eng. News-Rec., v. 134, no. 24, p. 833-837.

Pagan, A. R., 1962, Let's have more flood-plain regulation: Civil Engineering, v. 32, no. 5, p. 44-45. 
Riggs, H. C., 1961, Frequency of natural events: Am. Soc. Civil Engineers, Proc., v. 87, no. HY1, p. 15-26.

Thomas, D. M., 1964a, Floods in New Jersey, magnitude and frequency: New Jersey Dept. Conserv. and Econ. Devel., Div. Water Policy and Supply, Water Resources Circ. 13, 145 p. 1964b, Flood-depth frequency in New Jersey: New Jersey Dept. Conserv. and Econ. Devel., Div. Water Policy and Supply, Water Resources Circ. 14, $14 \mathrm{p}$.

Water Resources Council, 1967, A uniform technique for determining flood flow frequencies: Bulletin No. 15, U.S. Gov't Printing Office, Wash., D.C.

White, G. F., 1960, Strategic aspects of urban flood plain occupance: Am. Soc. Civil Engineers, Proc., v. 86, no. HY2, P. 89-102. 
onojzS y
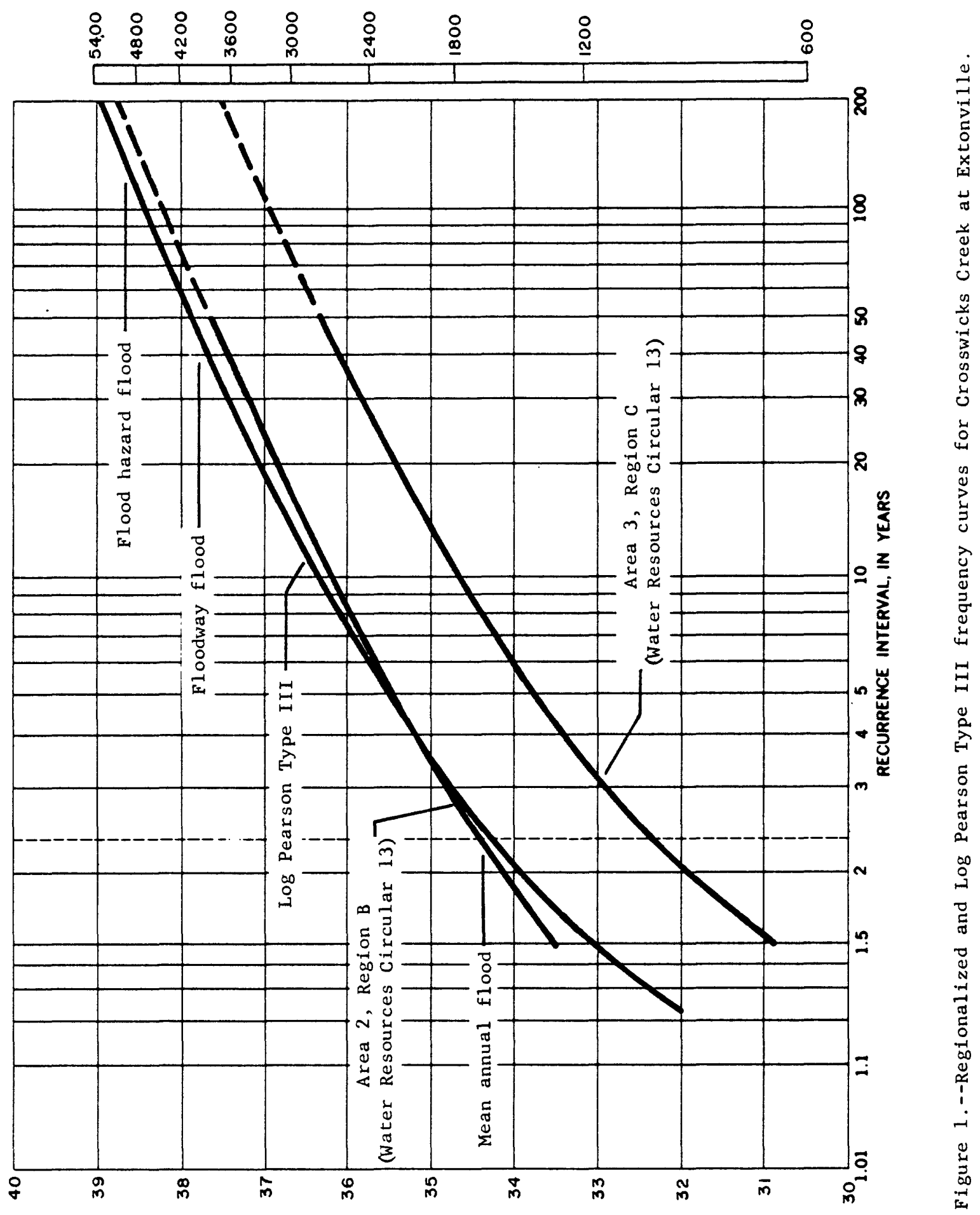

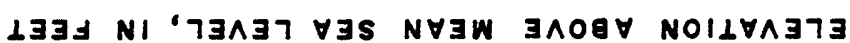




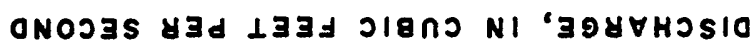

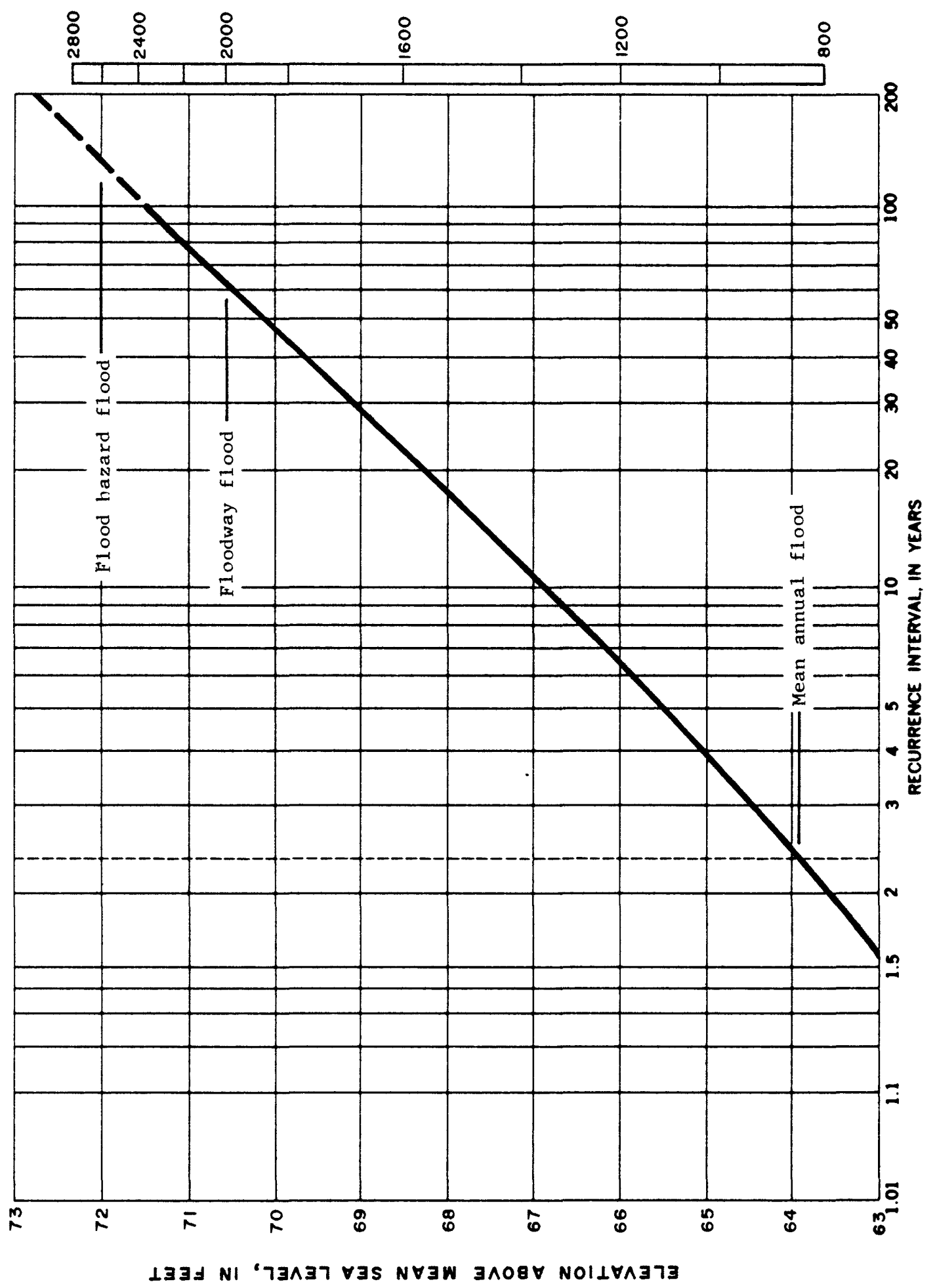

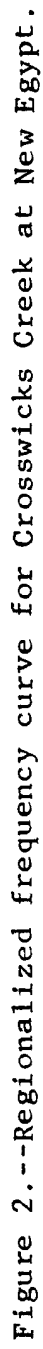




$$
\text { (page } 25 \text { follows) }
$$

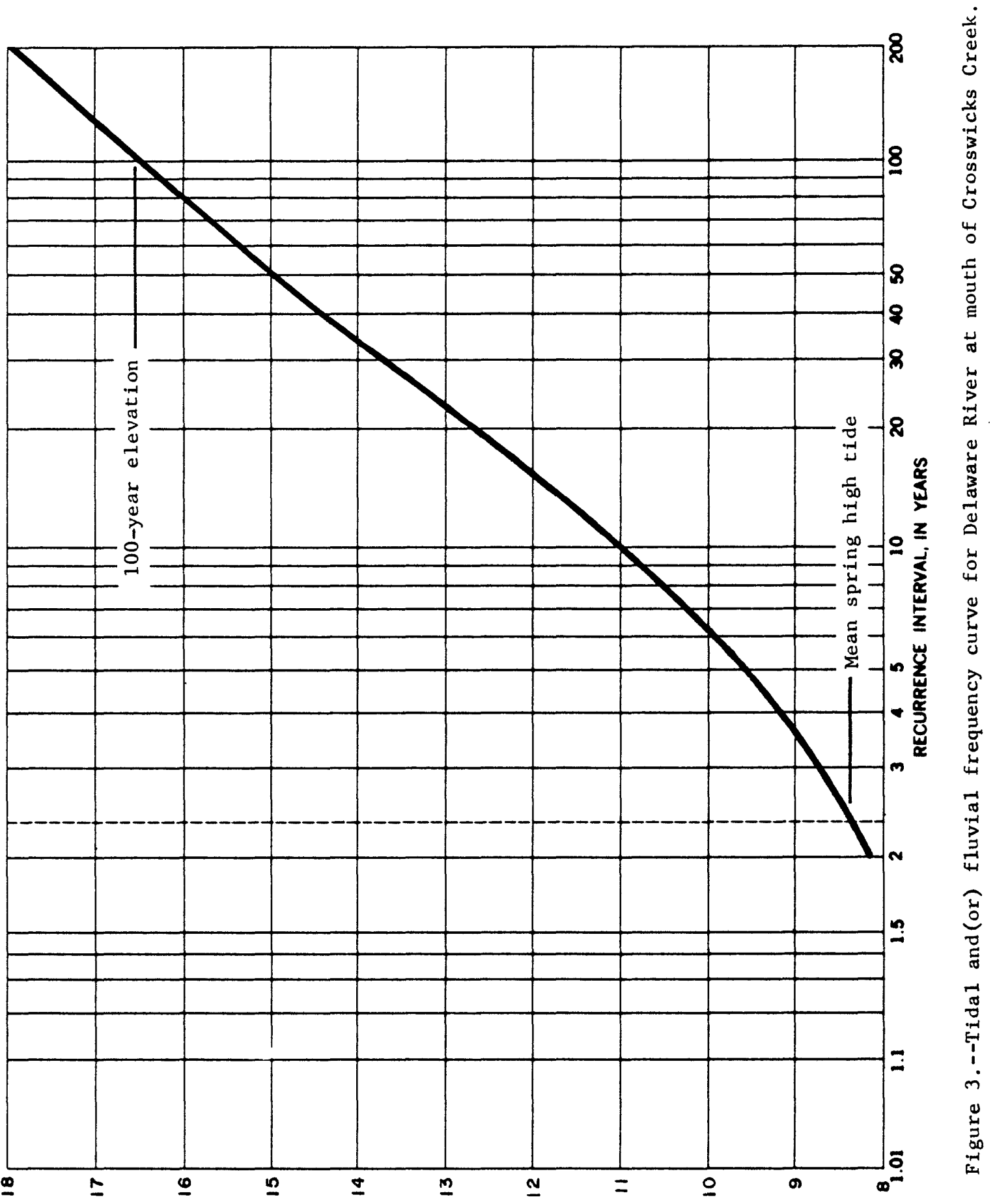




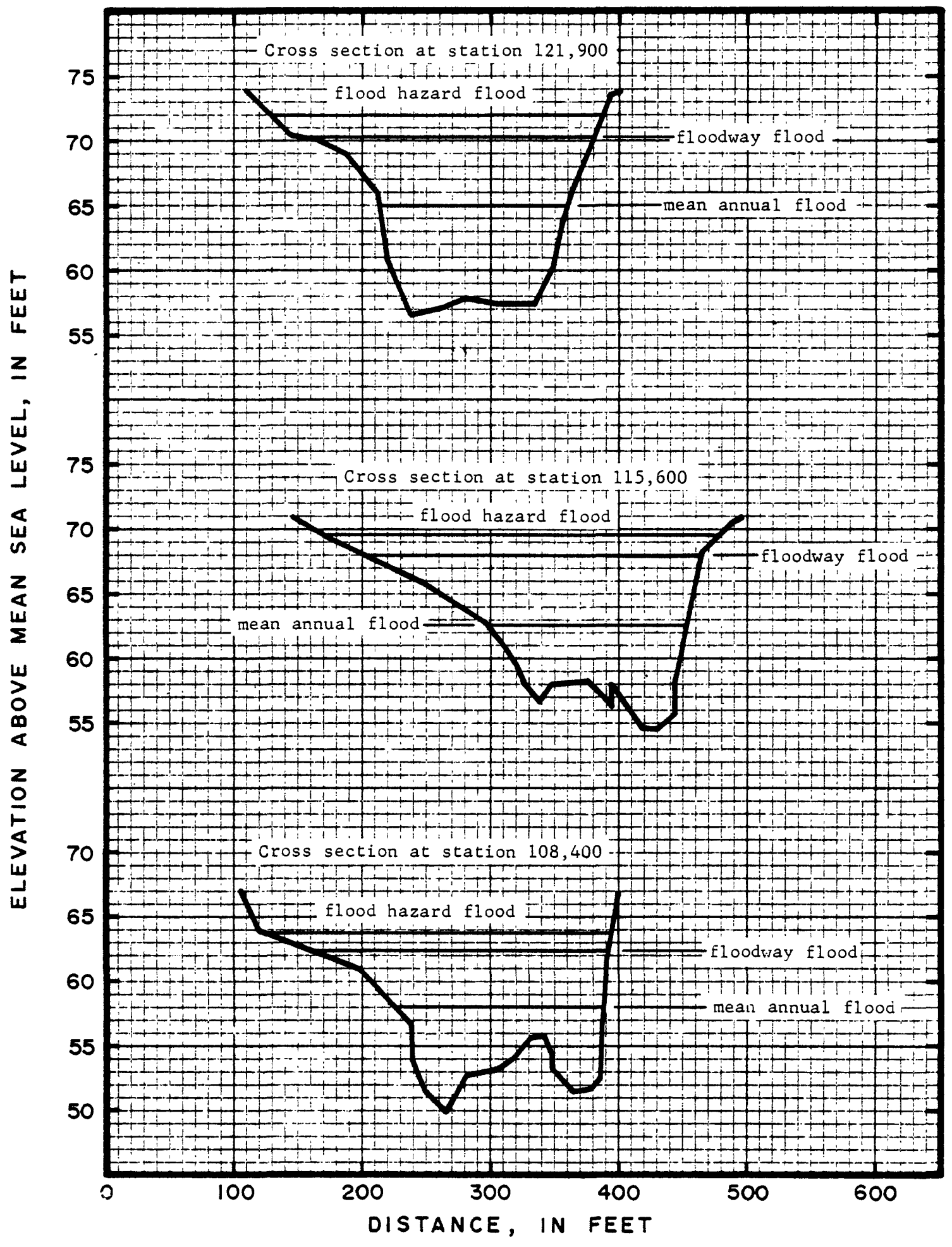

Figure 5.--Cross sections of Crosswicks Creek, looking downstream. 


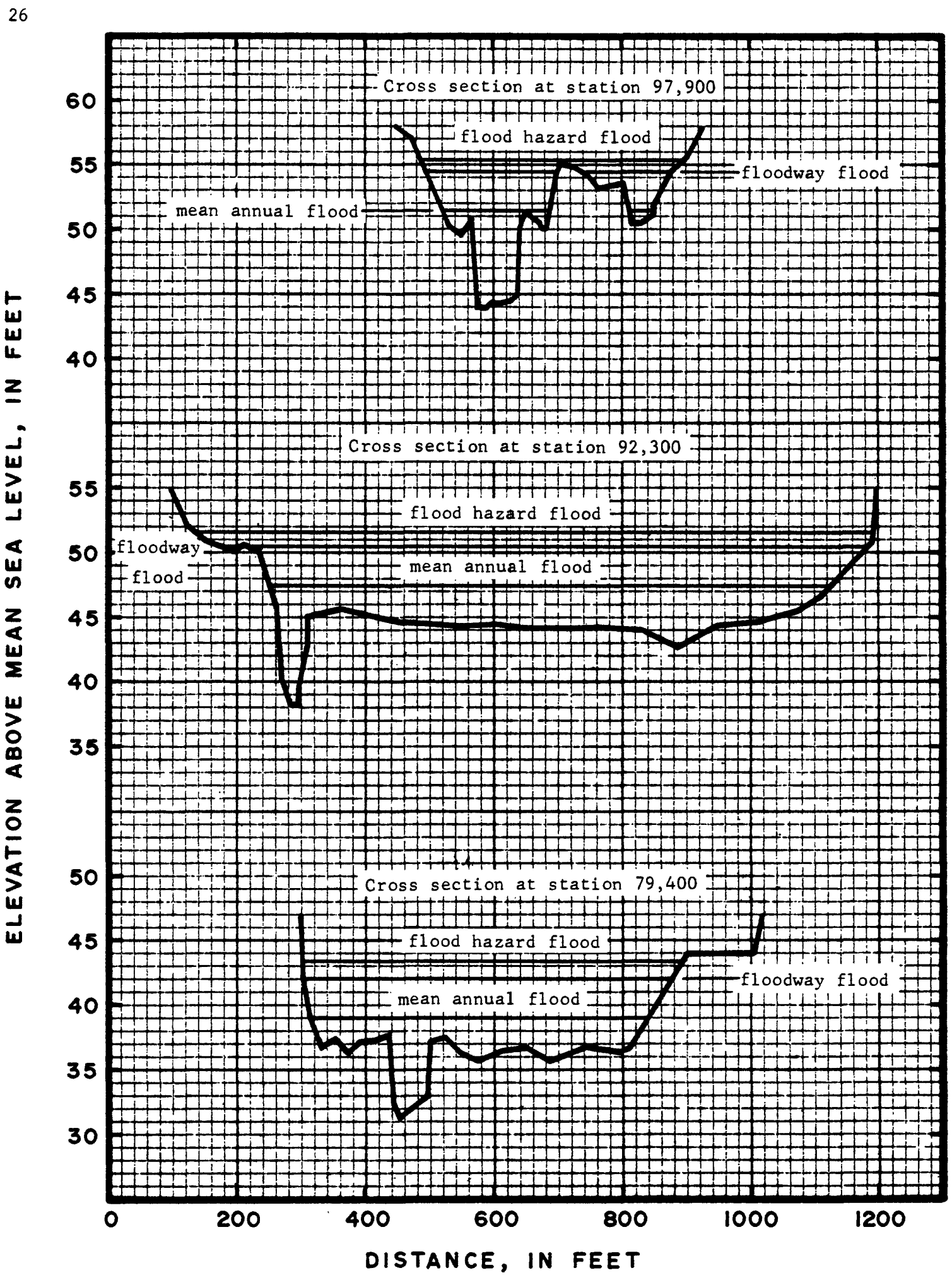

Figure 6.--Cross sections of Crosswicks Creek, looking downstream. 


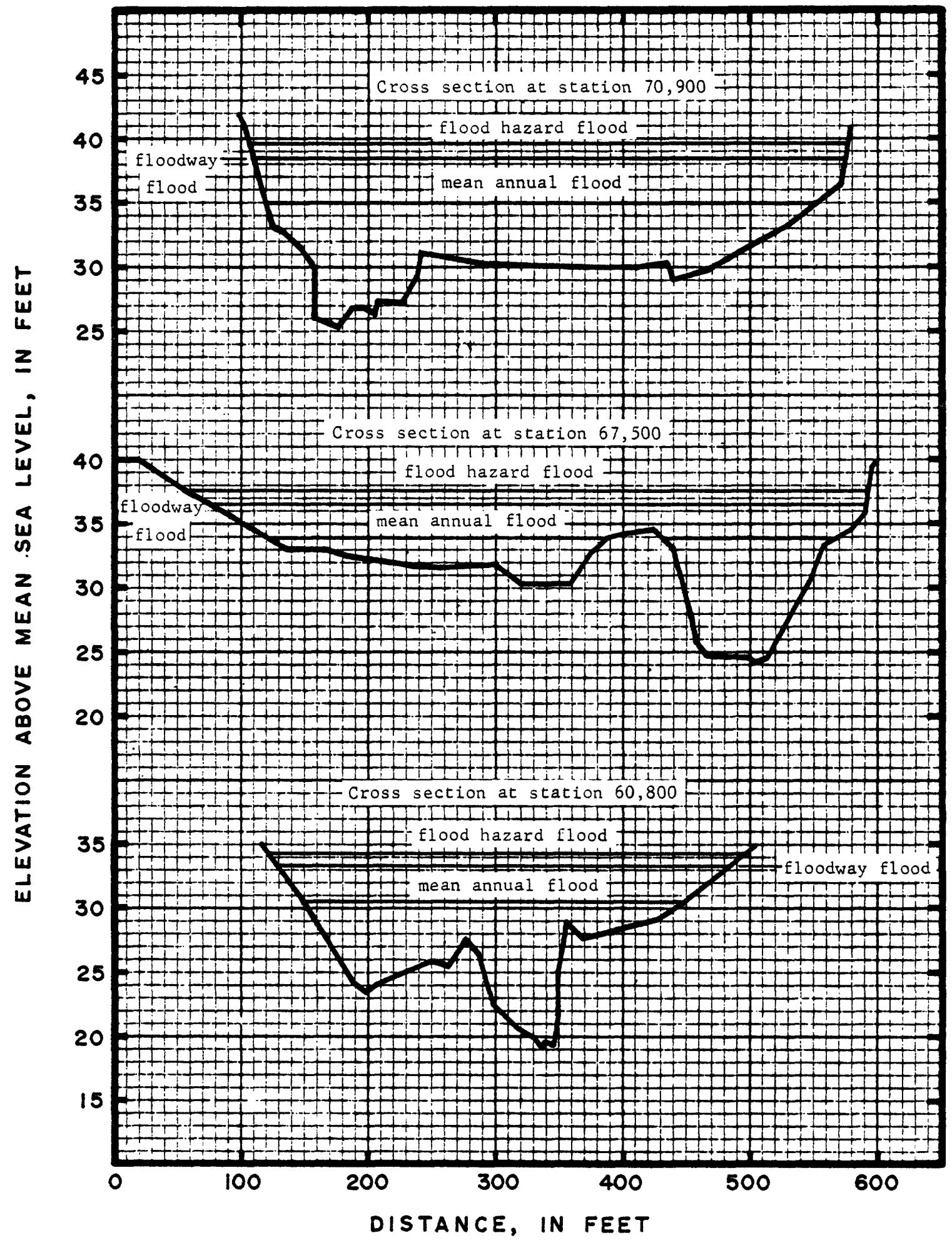

Figure 7.--Cross sections of Crosswicks Creek, looking downstream. 


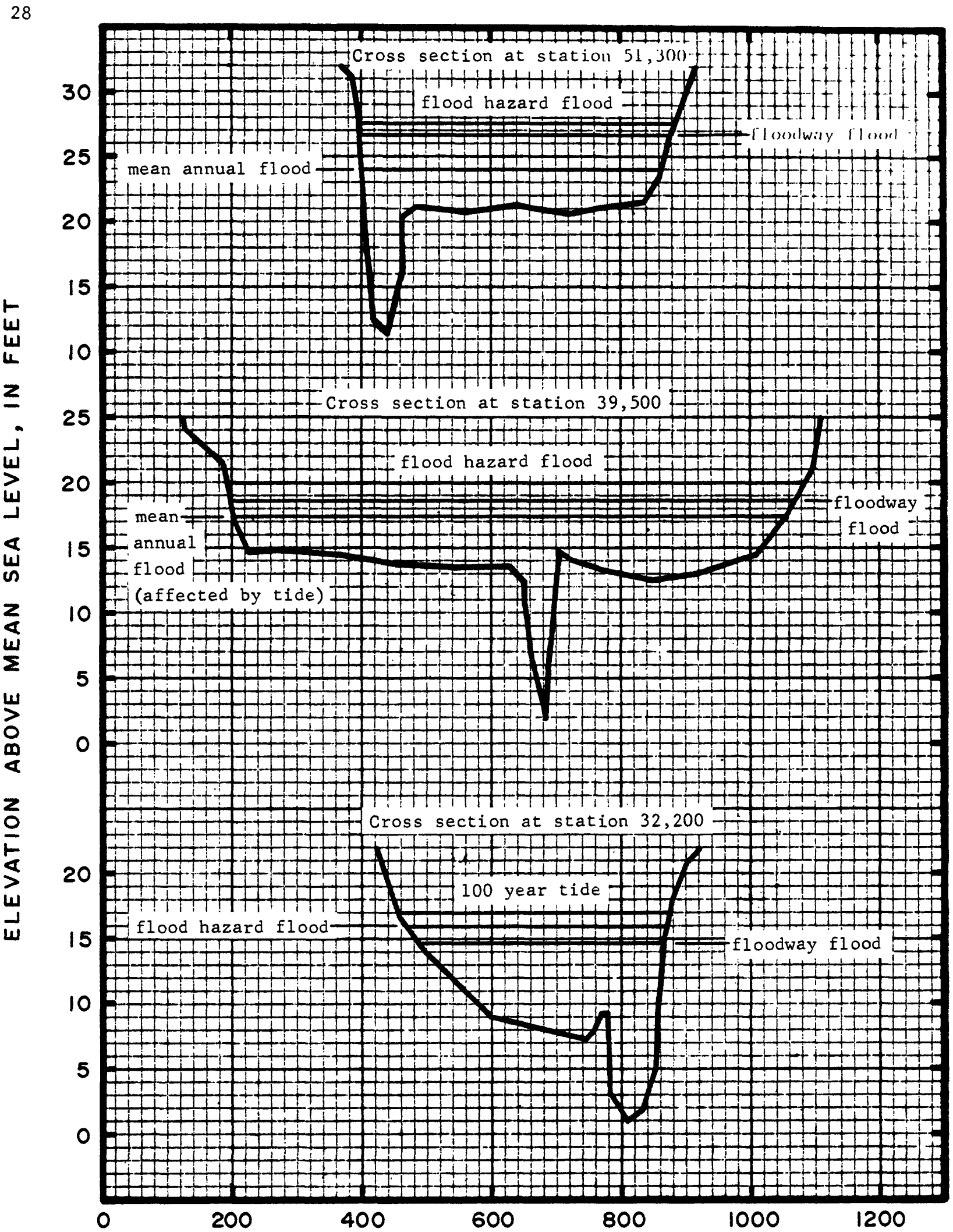

DISTANCE, IN FEET

Figure 8.--Cross sections of Crosswicks Creek, looking downstream. 


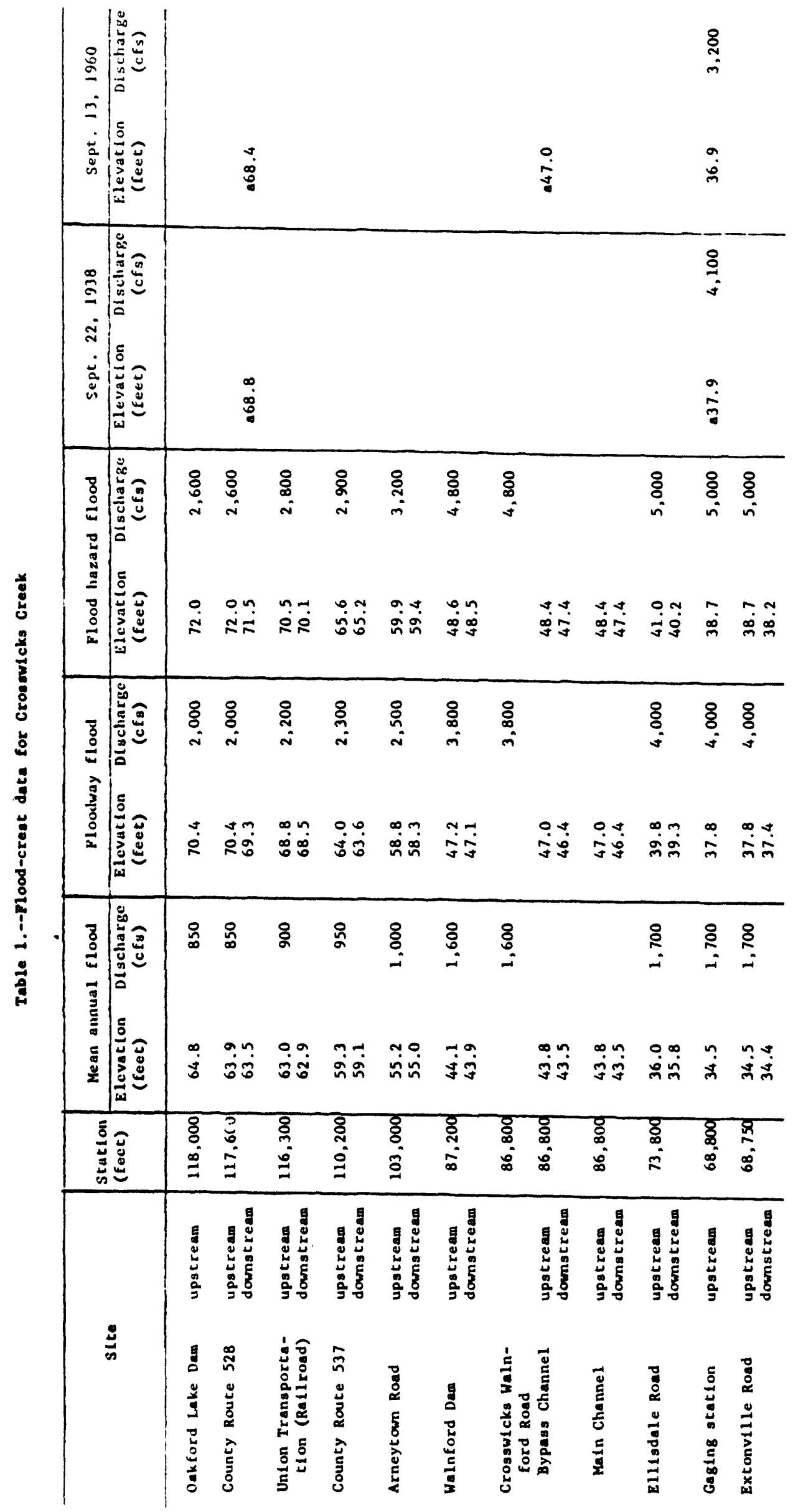




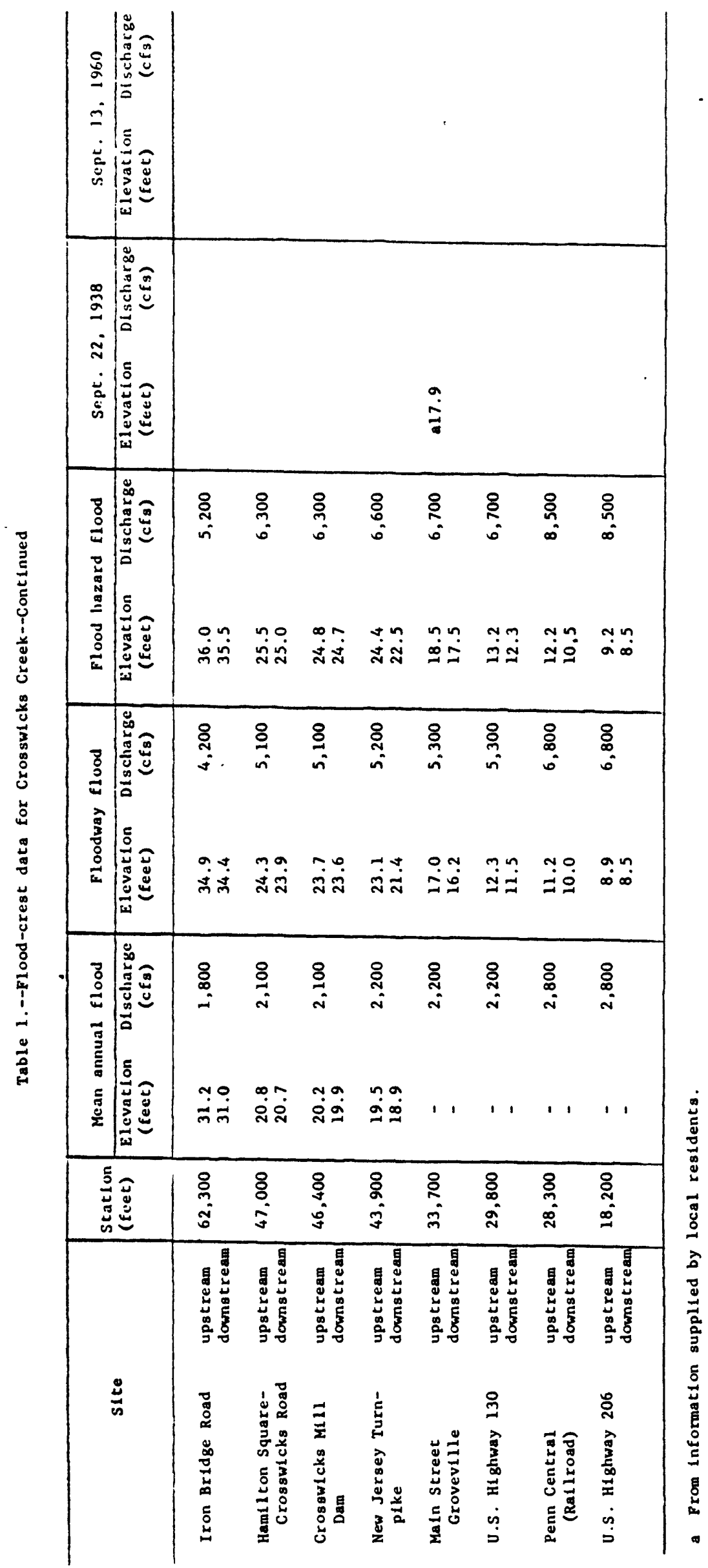




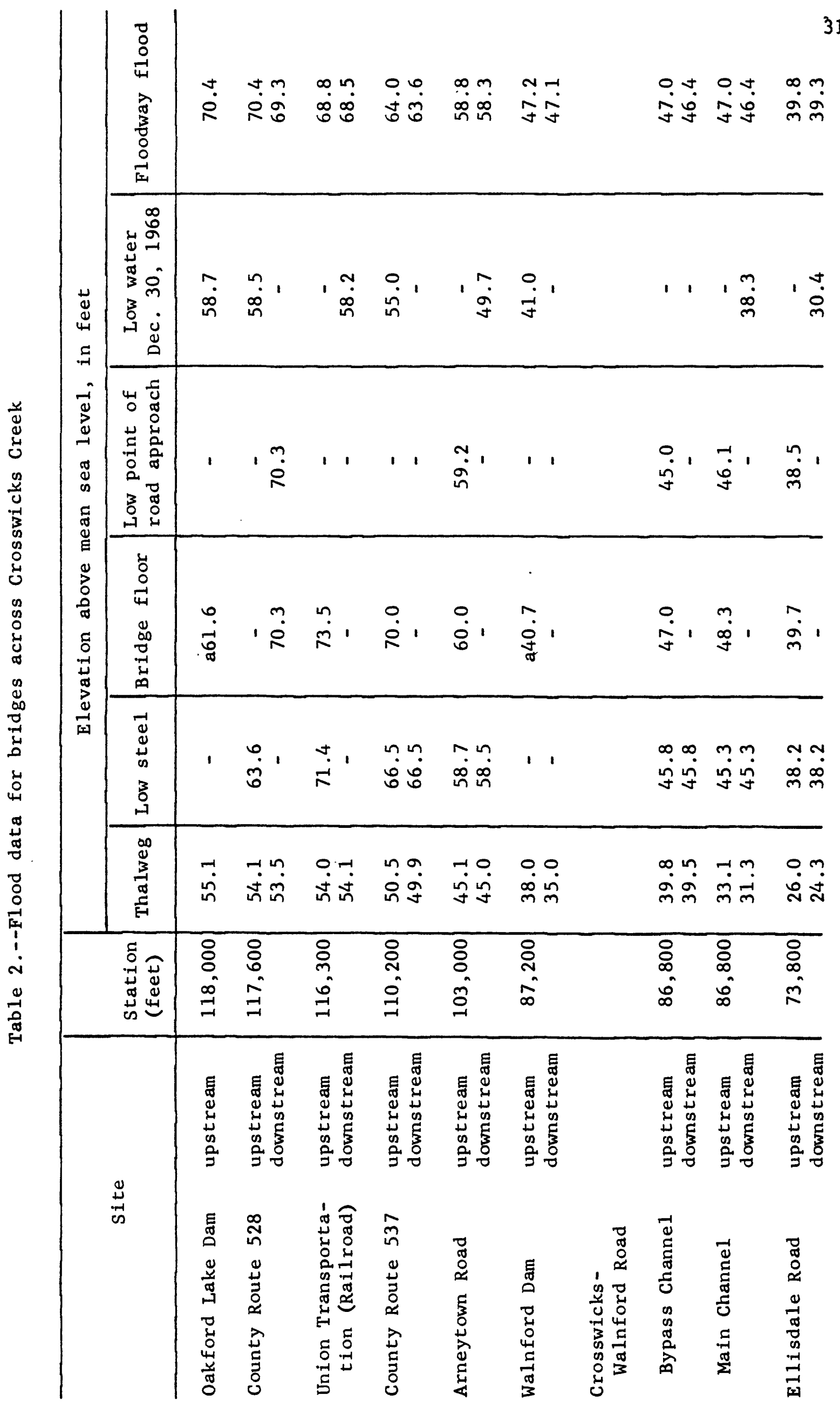




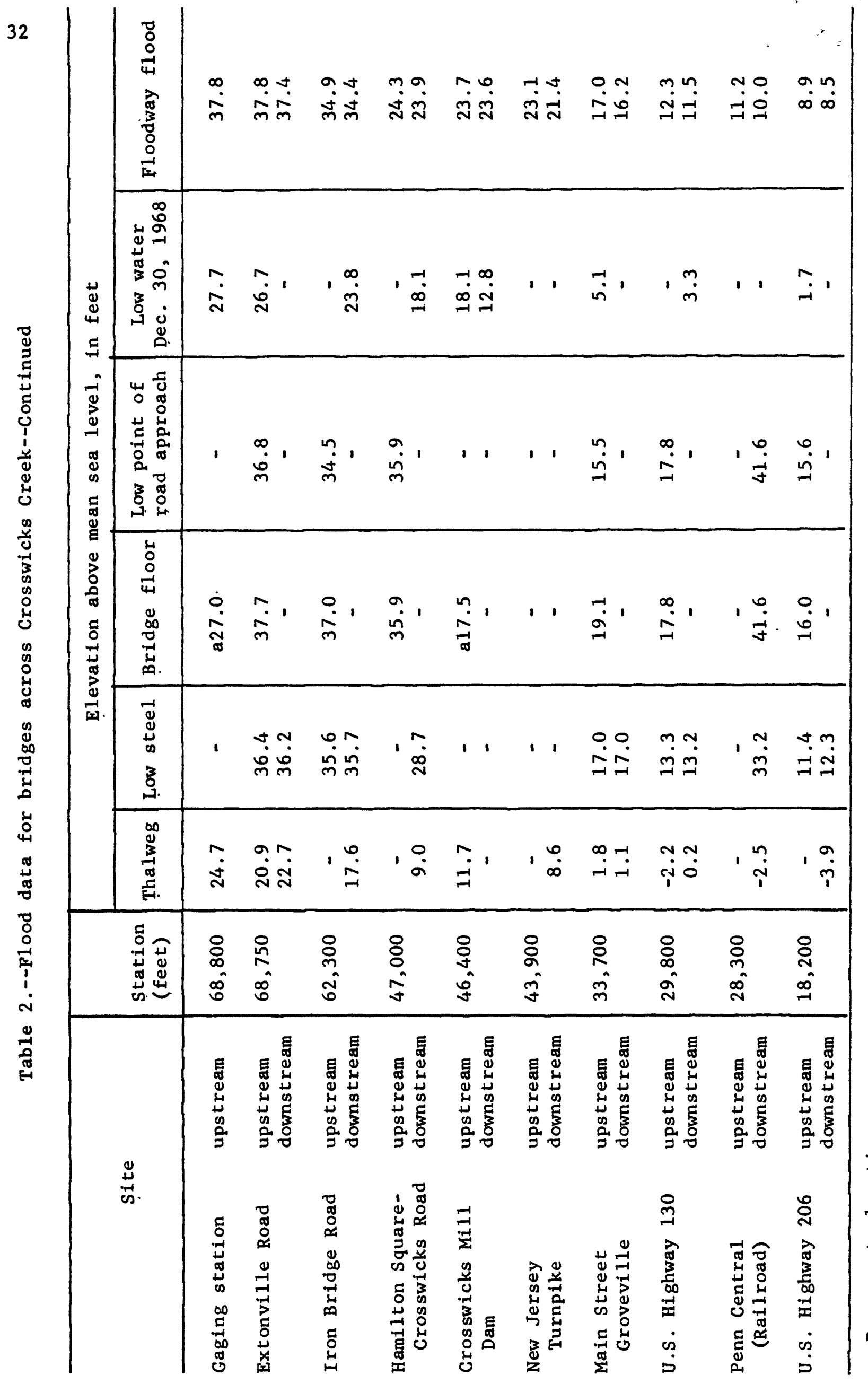


Table 3.--Mean sea level reference points

\begin{tabular}{|c|c|c|}
\hline $\begin{array}{l}\text { Distance } \\
\text { upstream } \\
\text { of mouth, } \\
\text { in feet }\end{array}$ & Description & $\begin{array}{l}\text { Elevation above } \\
\text { mean sea level, } \\
\text { in feet }\end{array}$ \\
\hline & Crosswicks Creek & \\
\hline 118,000 & $\begin{array}{l}\text { A chiseled square on the top corner of the } \\
\text { upstream left bank abutment of Oakford } \\
\text { Lake dam in New Egypt............... }\end{array}$ & 63.46 \\
\hline 117,600 & $\begin{array}{l}\text { N.J.G.C.S. RV } 5822 .-- \text { A standard monel metal } \\
\text { rivet on the downstream side of the } \\
\text { County Route } 528 \text { bridge (Main St, New } \\
\text { Egypt) over Crosswicks Creek, one foot to } \\
\text { right of the left end of the bridge.... } \\
\text { N.J.G.C.S. Monument } 3296 .- \text {-A standard } \\
\text { U.S.C. \& G.S. \& S.S. disk, set in con- } \\
\text { crete, on the east side of Evergreen } \\
\text { Road, about } 150 \text { ft north of the north } \\
\text { curb of Fort Avenue, in front of the } \\
\text { Norman Bright warehouse in New Egypt.... }\end{array}$ & 70.542 \\
\hline 116,300 & $\begin{array}{l}\text { The head of the first bolt from the up- } \\
\text { stream right bank end of, and through } \\
\text { the top of the } 6 " x 6 " \text { wooden curbing on } \\
\text { the Union Transportation railroad bridge } \\
\text { over Crosswicks Creek in New Egypt..... } \\
\text { N.J.G.C.S. Monument } 3295 .-- \text { A standard } \\
\text { U.S.C. \& G.S. \& S.S. disk, set in con- } \\
\text { crete, on the west side of the Allentown- } \\
\text { New Egypt road, about } 0.25 \text { mile south of } \\
\text { County Route } 537 \ldots \ldots \ldots \ldots \ldots\end{array}$ & 105.496 \\
\hline 110,200 & $\begin{array}{l}\text { The downstream right corner of the eleventh } \\
\text { vertical steel guardrail post from the } \\
\text { upstream left bank end of the County } \\
\text { Route } 537 \text { bridge over Crosswicks Creek... } \\
\text { N.J.G.C.S. RV } 6206 .- \text {-A standard monel metal } \\
\text { rivet in the northwest corner of a con- } \\
\text { crete culvert headwall on the west side } \\
\text { of the Allentown-New Egypt road, } 0.39 \\
\text { mile north of County Route } 537 \ldots . . . . . . .\end{array}$ & 81.021 \\
\hline
\end{tabular}


Table 3.--Mean sea level reference points--Continued

\begin{tabular}{|c|c|c|}
\hline $\begin{array}{l}\text { Distance } \\
\text { upstream } \\
\text { of mouth, } \\
\text { in feet }\end{array}$ & Description & $\begin{array}{l}\text { Elevation above } \\
\text { mean sea leve1, } \\
\text { in feet }\end{array}$ \\
\hline \multirow{4}{*}{103,000} & \multirow{3}{*}{ 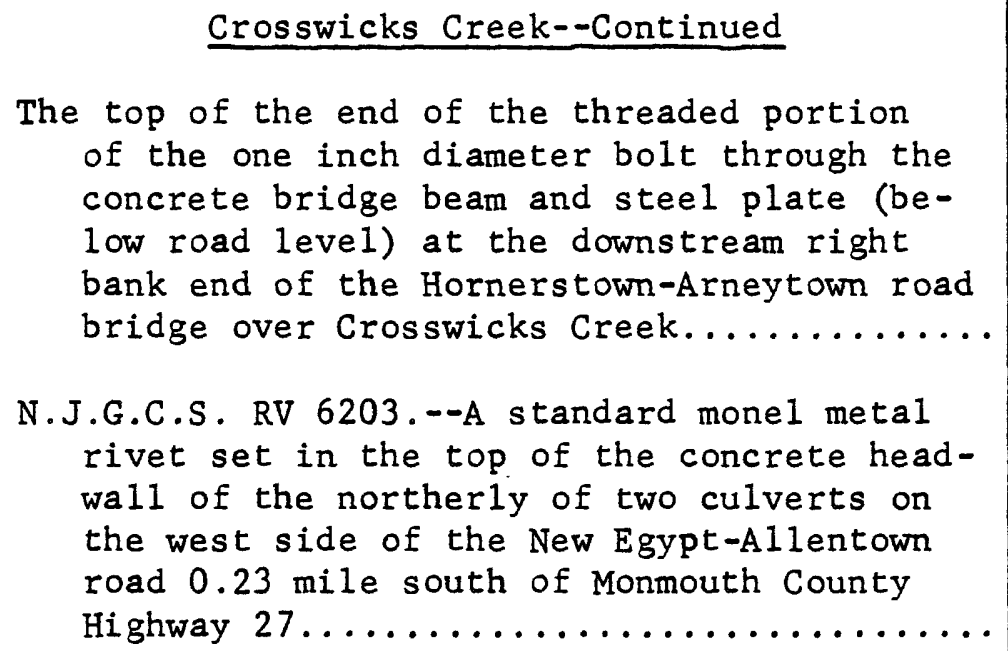 } & \multirow{4}{*}{59.30} \\
\hline & & \\
\hline & & \\
\hline & $\begin{array}{l}\text { N.J.G.C.S. Monument } 3291 .-- \text { A standard U.S.C. } \\
\text { \& G.S. \& S.S. disk, set in concrete on the } \\
\text { east side of County Route } 539 \text { about } 380 \\
\text { feet south of the dirt road to Walnford.... }\end{array}$ & \\
\hline 87,200 & 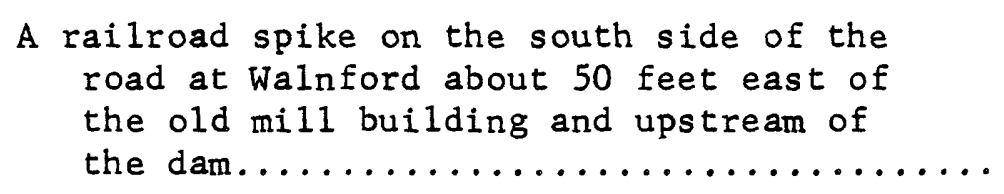 & 50.42 \\
\hline 86,800 & 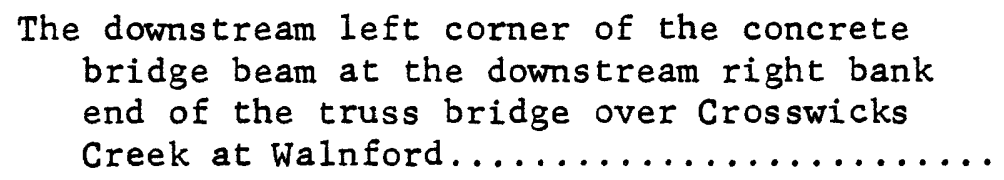 & 46.11 \\
\hline 73,800 & 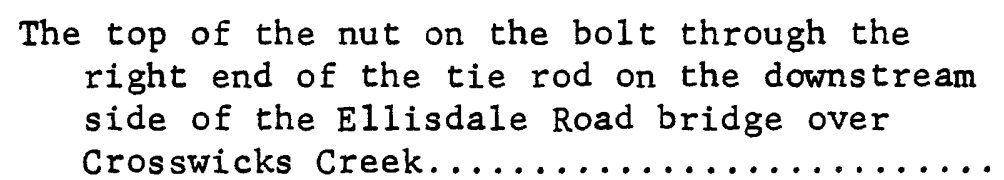 & \\
\hline
\end{tabular}


Table 3.--Mean sea level reference points--Continued

\begin{tabular}{|c|c|c|}
\hline $\begin{array}{l}\text { Distance } \\
\text { upstream } \\
\text { of mouth, } \\
\text { in feet }\end{array}$ & Description & $\begin{array}{l}\text { Elevation above } \\
\text { mean sea level, } \\
\text { in feet }\end{array}$ \\
\hline 68,700 & 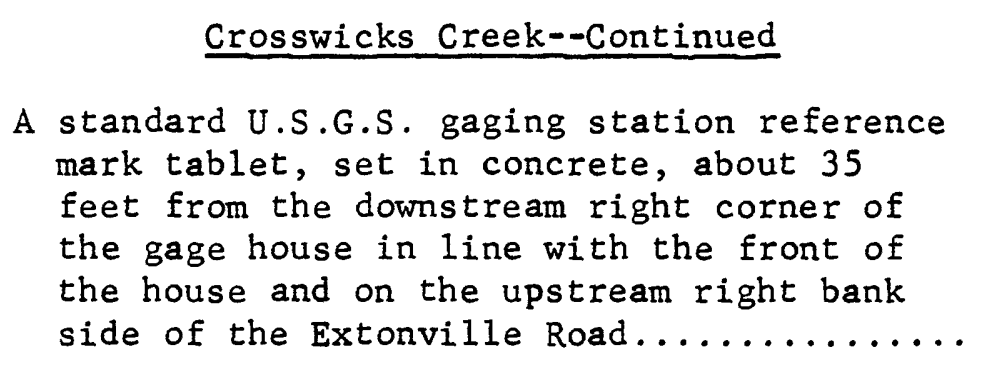 & 33.08 \\
\hline 62,200 & 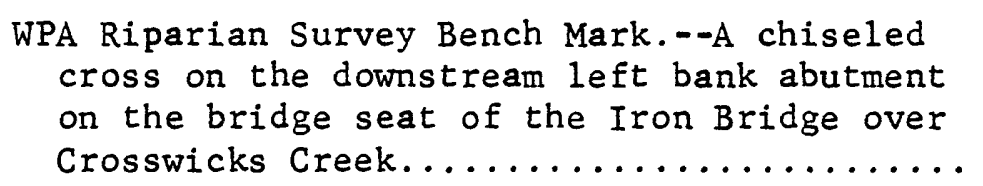 & 35.61 \\
\hline 47,000 & 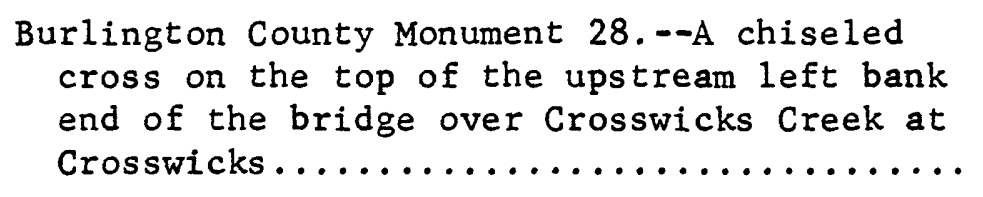 & 36.04 \\
\hline 46,400 & $\begin{array}{l}\text { The top of the upstream corner of the down- } \\
\text { stream left bank main dam abutment on } \\
\text { Crosswicks Creek at Crosswicks............ }\end{array}$ & 21.69 \\
\hline 33,700 & 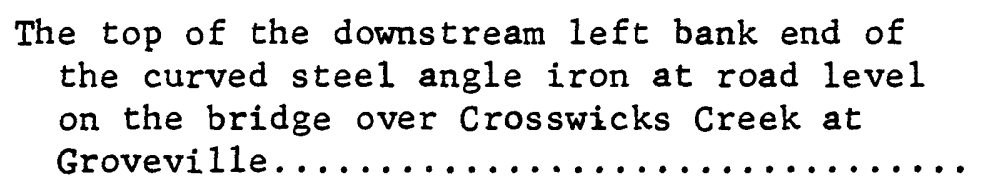 & 19.77 \\
\hline 29,700 & 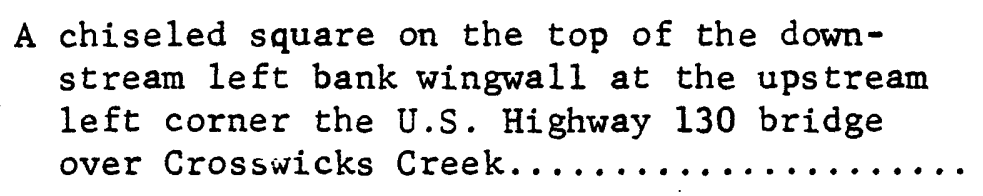 & 17.85 \\
\hline 18,200 & $\begin{array}{l}\text { The top downstream left corner of the drop } \\
\text { inlet at the upstream right bank end of } \\
\text { the U.S. Highway } 206 \text { bridge over Cross- } \\
\text { wicks Creek. (Labeled as "BM } 32 \text { " by } \\
\text { unknown persons.) }\end{array}$ & 16.530 \\
\hline
\end{tabular}


Table 3.--Mean sea level reference points--Continued

\begin{tabular}{|c|c|c|}
\hline $\begin{array}{l}\text { Distance } \\
\text { upstream } \\
\text { of mouth, } \\
\text { in feet }\end{array}$ & Description & $\begin{array}{c}\text { Elevation above } \\
\text { mean sea level, } \\
\text { in feet }\end{array}$ \\
\hline 18,200 & 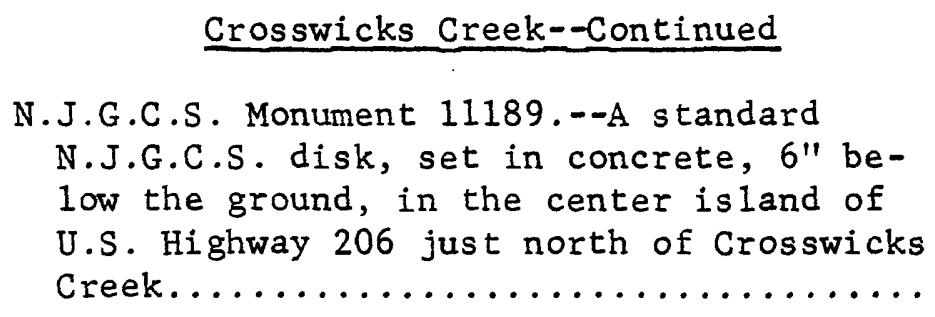 & 16.937 \\
\hline
\end{tabular}

